\title{
水酸化アルミニウムによるアルカリ骨材反応抑制効果
}

$$
\begin{aligned}
& \text { 石井あきな* 藤井隆史 }{ }^{* *} \text { 渡辺純一 } * * * \\
& \text { 片岡宏治*** 綾野克 紀 }{ }^{* * * *}
\end{aligned}
$$

\section{Effect of Aluminum Hydroxide on Control of Alkali-Aggregate Reaction}

by

\author{
Akina IshiI ${ }^{*}$, Takashi FujII ${ }^{* *}$, Jun-ichi Watanabe ${ }^{* * *}$, \\ Koji KatAoKA $^{* * *}$ and Toshiki Ayano ${ }^{* * * *}$
}

\begin{abstract}
Alkali-aggregate reaction (AAR) is one of serious problems of concrete. It is known that fly ash, blast furnace slag, and so on can control the expansion of concrete by AAR. Natural zeolite is known as material that control AAR expansion, too. This paper shows the effect of aluminum hydroxide on control the expansion of concrete by AAR. It is possible to control the expansion of concrete by AAR when aluminum hydroxide to binder ratio is $4.0 \%$. Especially, when a little of fly ash is combined, the effect of aluminum hydroxide is big. But, when aluminum hydroxide is used with much fly ash, the effect of aluminum hydroxide is not clear. The effect of aluminum hydroxide appears when it dissolves in concrete. In this paper, three different type of aggregate were used in order to clarify the effect of aluminum hydroxide on the expansion of concrete by AAR. The effect of aluminum hydroxide on AAR is somewhat different in the type of aggregate. However, it will clarify that aluminum hydroxide is one of an effective admixture to control the expansion of concrete by AAR. By combining aluminum hydroxide with adequate quantity of fly ash, big effect to control the expansion of concrete by AAR can be expected.
\end{abstract}

Key words : Aggregate, Alkali-aggregate reaction, Aluminum hydroxide, Fly ash, Zeolite

\section{1 緒 \\ 言}

アルカリ骨材反応は，コンクリート構造物に重大な劣 化を及ぼす要因の一つである。コンクリート内部の細孔 溶液中に含まれるナトリウムイオンやカリウムイオンと 骨材中のシリカ質を含む鉱物との化学反応によって，ア ルカリシリカゲルが生成される。アルカリシリカゲルが 吸水することで，コンクリートは膨張し，大きなひび割 れや鉄筋の破断が起こり，著しい性能低下がコンクリー 卜構造物に生じる.1)

アルカリ骨材反応を防止する目的で，化学法あるいは モルタルバー法の試験が JIS に規定され，一般に無害と 判定された骨材が多く用いられている。その一方で，無 害と判定される骨材の供給量が十分とはいえないほど， コンクリート用骨材の資源枯渇が問題となっている。ま た，コンクリート塊より再生される骨材が普及するにつ れて，アルカリ骨材反応によって劣化を生じた構造物か ら再生された骨材が混入する恐れも懸念されている。ア ルカリ骨材反応を抑制する混和材には，フライアッシュ，

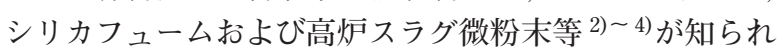
ている。また，使用実績は少ないが，天然ゼオライトも アルカリ骨材反応を抑制する材料である.5), 6)

本研究は，水酸化アルミニウムを用いることにより，
少ない混和材の使用量で，アルカリ骨材反応を抑制する 手法を検討したものである，水酸化アルミニウムとフラ イアッシュを適切な量で併用することにより, 少量の混 和材で，フライアッシュのみ，あるいは，水酸化アルミ ニウムのみを大量に用いた場合と同程度に，アルカリ骨 材反応を抑制できることを示す。

\section{$2 \cdot 1$ 使用材料}

\section{2 実 験 概 要}

$\mathbf{2} \cdot \mathbf{1} \cdot \mathbf{1}$ 骨材 骨材には, 四国産の安山岩砕石 Type $\mathrm{T}$ (密度: $2.50 \mathrm{~g} / \mathrm{cm}^{3}$, 吸水率 : $2.37 \%$ ), 北海道産の安山 岩砕石 Type H（密度： $2.69 \mathrm{~g} / \mathrm{cm}^{3}$, 吸水率 : $2.10 \%$ ), 九州産の安山岩砕石 Type K (密度 : $2.76 \mathrm{~g} / \mathrm{cm}^{3}$, 吸水 率：1.48\%） および旭川水系の川砂 Type N（密度： $2.62 \mathrm{~g} / \mathrm{cm}^{3}$, 吸水率：1.82\%）を用いた. Type T, Type H およびType K の骨材を JIS A $1145 ： 2001$ 「骨材のア ルカリシリカ反応性試験方法 (化学法)」に従い試験し た結果を Fig. 1 に示す。また，実験には，30 年間海洋 構造物として供用され，アルカリ骨材反応によって劣化 を生じたコンクリート塊から作成した再生細骨材も用い た。なお，本文中でとくに示さない限り，実験結果は Type Tの骨材を用いたものである.

$2 \cdot 1 \cdot 2$ 水酸化アルミニウム 実験には，工業用水

\footnotetext{
$\dagger$ 原稿受理 平成 18 年 11 月 8 日 Received Nov. 8, 2006 @ 2007 The Society of Materials Science, Japan

* 岡山大学大学院環境学研究科 ₹700-8530 岡山市津島中, Graduate School of Env. Sci., Okayama Univ., Tsushima-naka, Okayama, 700-8530

** 正 会員 岡山大学大学院環境学研究科 ₹700-8530 岡山市津島中, Graduate School of Env. Sci., Okayama Univ., Tsushima-naka, Okayama, $700-8530$

*** 正 会 員 大阪兵庫生コンクリート工業組合 †530-0001 大阪市北区梅田, Osaka-Hyogo Ready-Mixed Concrete Industrial Assoc., Kita-ku, Osaka, 530-0001

**** 正 会 員 岡山大学マネジメント廃棄物研究センター †700-8530 岡山市津島中, Waste Management Res. Center, Okayama Univ., Tsushima-
} naka, Okayama, 700-8530 


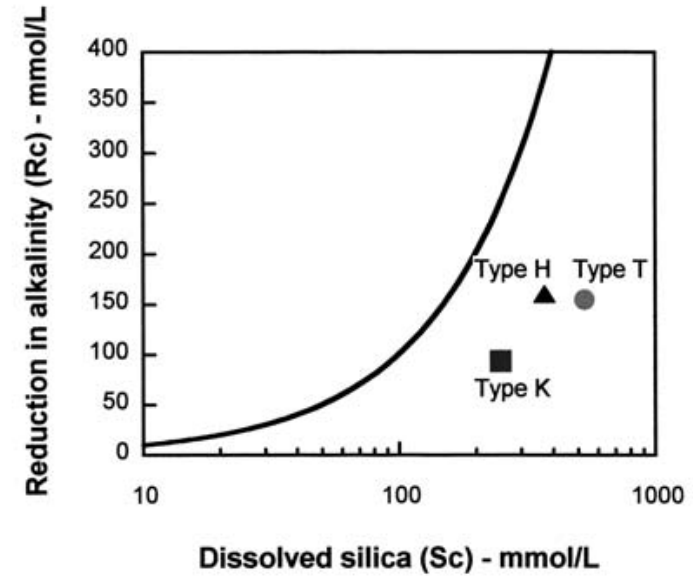

Fig. 1 Result of chemical method.

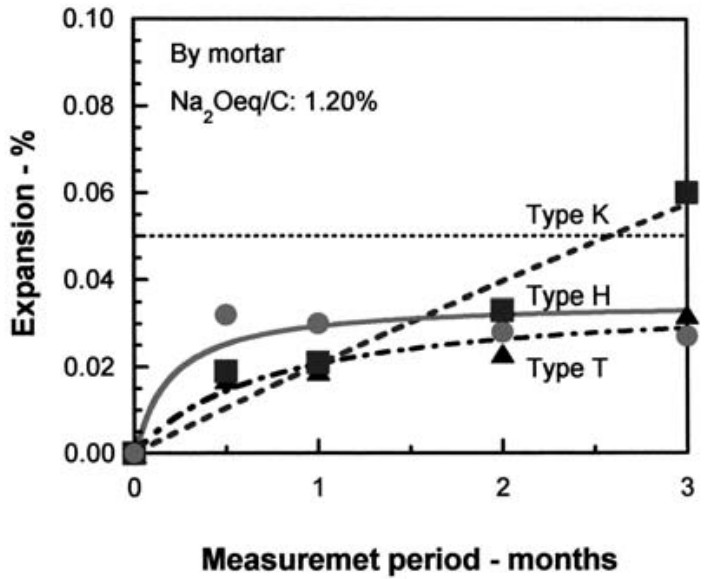

Fig. 2 Result of mortar-bar method.
Table 1 Mixture proportions of mortar. (Unit: g/batch)

\begin{tabular}{|c|c|c|c|c|}
\hline \multirow{2}{*}{ W } & \multicolumn{3}{|c|}{ Binder } & \multirow{2}{*}{ S } \\
\hline & $\mathrm{C}$ & Fly ash & $\mathrm{Al}(\mathrm{OH})_{3}$ & \\
\hline \multirow{13}{*}{300} & 600.0 & 0.0 & 0.0 & \multirow{13}{*}{1,350} \\
\hline & 570.0 & 21.0 & \multirow{3}{*}{0.0} & \\
\hline & 540.0 & 41.9 & & \\
\hline & 480.0 & 83.8 & & \\
\hline & 588.3 & \multirow{3}{*}{0.0} & 8.1 & \\
\hline & 576.5 & & 16.2 & \\
\hline & 564.8 & & 24.3 & \\
\hline & 558.3 & \multirow{3}{*}{21.0} & 8.1 & \\
\hline & 546.5 & & 16.2 & \\
\hline & 534.8 & & 24.3 & \\
\hline & 528.3 & \multirow{3}{*}{41.9} & 8.1 & \\
\hline & 516.5 & & 16.2 & \\
\hline & 504.8 & & 24.3 & \\
\hline
\end{tabular}

酸化アルミニウム（密度 : $2.17 \mathrm{~g} / \mathrm{cm}^{3}$, 平均粒子径： $50 \mu \mathrm{m} ）$ を用いた。水酸化アルミニウムは, 酸およびアル カリには溶解するが，中性の水およびアルコールには不 溶であることが知られている.

$2 \cdot 1 \cdot 3$ ゼオライト ゼオライトには，核にナトリウ ムイオンをもつ合成 $\mathrm{A}$ 型ゼオライトを用いた。合成 $\mathrm{A}$ 型 ゼオライトの組成式は, $\mathrm{Na}_{2} \mathrm{O} \cdot \mathrm{Al}_{2} \mathrm{O}_{3} \cdot 2 \mathrm{SiO}_{2} \cdot 4.5 \mathrm{H}_{2} \mathrm{O}$ である。

\section{$2 \cdot 2$ 配合}

$2 \cdot 2 \cdot 1$ モルタルの配合 本実験に使用したモルタ ルの配合を Table 1 に示す。この配合は, JIS A 1146： 2001 「骨材のアルカリシリカ反応性試験方法（モルタル バー法)」に準じたものである。本実験に扎いて，フライ アッシュおよび水酸化アルミニウムがアルカリ骨材反応 を抑制する効果をモルタルを用いて確認する場合には， 結合材の体積が一定となる配合としている。セメントは, 普通ポルトランドセメント (密度 $: 3.15 \mathrm{~g} / \mathrm{cm}^{3}$, ブレー ン值：3,300 $\left.\mathrm{cm}^{2} / \mathrm{g}\right)$ を, フライアッシュは, JIS A $6201 ： 1999$ (2004 確認) に規定されるフライアッシュ II 種（密度： $2.20 \mathrm{~g} / \mathrm{cm}^{3}$ ) を用いた。

$\mathbf{2} \cdot \mathbf{2} \cdot \mathbf{2}$ コンクリートの配合 本実験に使用したコ ンクリートの配合を Table 2 に示す。一般的な土木用コ ンクリートを想定して配合を決定した。フライアッシュ
Table 2 Mixture proportions of concrete.

\begin{tabular}{|c|c|c|c|c|c|c|c|c|c|c|}
\hline \multirow{3}{*}{$\begin{array}{c}\mathrm{G}_{\max } \\
(\mathrm{mm})\end{array}$} & \multirow{3}{*}{$\begin{array}{c}\text { W/B/B } \\
(\%)\end{array}$} & \multirow{3}{*}{$\begin{array}{l}\text { s/a } \\
(\%)\end{array}$} & \multirow{3}{*}{$\begin{array}{l}\text { Air } \\
(\%)\end{array}$} & \multicolumn{6}{|c|}{ Unit content $\left(\mathrm{kg} / \mathrm{m}^{3}\right)$} & \multirow{3}{*}{$\begin{array}{l}\mathrm{AE}^{* * *} \\
\left(\mathrm{~g} / \mathrm{m}^{3}\right)\end{array}$} \\
\hline & & & & \multirow{2}{*}{ W } & \multicolumn{3}{|c|}{ Binder } & \multirow{2}{*}{$S$} & \multirow{2}{*}{ G } & \\
\hline & & & & & $\mathrm{C}$ & $\mathrm{FA}^{*}$ & $\mathrm{Al}^{* *}$ & & & \\
\hline \multirow{4}{*}{20} & 60.0 & \multirow{4}{*}{42.5} & \multirow{4}{*}{4.5} & \multirow{4}{*}{180} & 300 & 0 & 0 & \multirow{4}{*}{757} & \multirow{4}{*}{1,051} & \multirow{4}{*}{9.0} \\
\hline & 64.1 & & & & 239 & 42 & 0 & & & \\
\hline & 61.9 & & & & 262 & $\mathbf{0}$ & 29 & & & \\
\hline & 61.9 & & & & 268 & 10 & 13 & & & \\
\hline
\end{tabular}

${ }^{*}$ FA: Fly ash ${ }^{* *} \mathrm{Al}$ : Aluminum hydroxide ${ }^{* * *} \mathrm{AE}$ : Air entraining agent

Table 3 Mixture proportions of concrete.

\begin{tabular}{|c|c|c|c|c|c|c|c|c|}
\hline \multirow{2}{*}{$\begin{array}{l}G_{\max } \\
(\mathrm{mm})\end{array}$} & \multirow{2}{*}{$\begin{array}{c}\text { W/C } \\
(\%)\end{array}$} & \multirow{2}{*}{$\begin{array}{l}\text { s/a } \\
(\%)\end{array}$} & \multirow{2}{*}{$\begin{array}{l}\text { Air } \\
(\%)\end{array}$} & \multicolumn{4}{|c|}{ Unit content $\left(\mathrm{kg} / \mathrm{m}^{3}\right)$} & \multirow{2}{*}{$\begin{array}{l}\mathrm{AE}^{* * *} \\
\left(\mathrm{~g} / \mathrm{m}^{3}\right)\end{array}$} \\
\hline & & & & W & $\mathrm{C}$ & S & $\mathrm{G}$ & \\
\hline 20 & 60.0 & 44.0 & 4.5 & 175 & 292 & 801 & 954 & 8.8 \\
\hline
\end{tabular}

のみを用いた場合，水酸化アルミニウムのみを用いた場 合扎よ゙フライアッシュと水酸化アルミニウムを併用し た場合の効果を確認するために，単位水量，単位骨材量 および結合材の体積が一定となる配合とした。 $\mathrm{AE}$ 剂は， $1 \mathrm{~m}^{3}$ あたり $9.0 \mathrm{~g}$ で一定とし，水と置換して用いた。 セメ ントは，普通ポルトランドセメントを，フライアッシュ は, JIS A 6201 ：1999（2004 確認）に規定されるフライ アッシュ II 種（密度： $2.20 \mathrm{~g} / \mathrm{cm}^{3}$ ）を用いた。

$2 \cdot 2 \cdot 3$ 水酸化ナトリウムの使用量 Fig. 2 に, Type T, Type H およびType Kの骨材を, モルタルバー 法（JIS A 1146：2001）に従い試験した結果を示す。乇 ルタルバー法では，モルタル中の全アルカリ量が，酸化 ナトリウム当量でセメントの $1.2 \%$ （質量比）になるよう に規定している。Fig. 3 にTable 1 に示した配合で， Type T およびType N の骨材を用いたモルタルの膨張量 を示す。なお，罒中の破線は，モルタルバー法で無害で ないと判定される $0.1 \%$ の膨張を示している。この条件で は，Type Tの骨材では， $0.2 \%$ 以上の有害な膨張を生じ ているのに対し, Type Nの骨材では, 有害な膨張を生 じていない。この結果をもとに, 本実験で用いたモルタ ルは, 混和材のアルカリ量に関係なく, 1 バッチあたり 酸化ナトリウム当量で $9.3 \mathrm{~g}$ の水酸化ナトリウムを添加し 


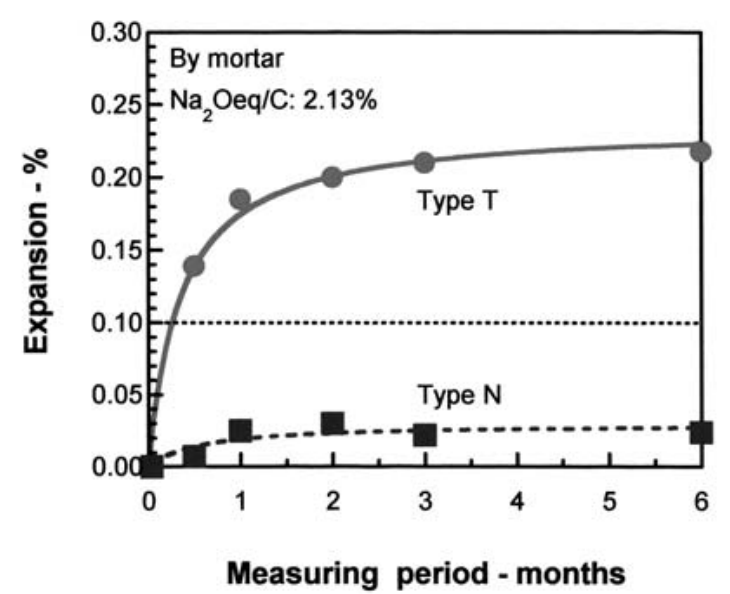

Fig. 3 Expansion of mortar with Type T and Type N.

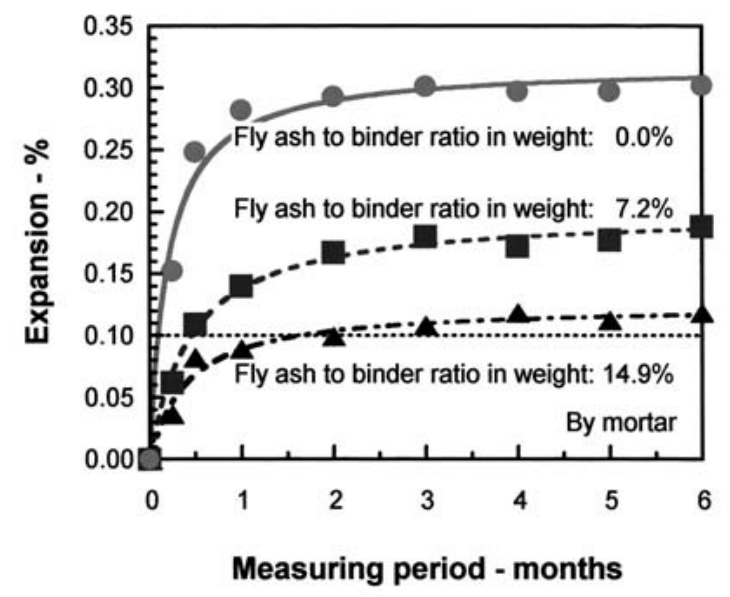

Fig. 5 Effect of fly ash on expansion of mortar.

た.このとき, Table 1 に示される混和材を用いていな い配合の全アルカリ量は, 酸化ナトリウム当量で, セメ ントの $2.13 \%$ となる.

Fig. 4 に，細骨材にType Nを，粗骨材にType T を 用いたコンクリートの膨張量を示す。これらの結果は， Table 3 に示されるコンクリートを用いたものである. 困 中の○，口および $\triangle$ は，それぞれ，水酸化ナトリウムの添 加量が酸化ナトリウム当量で $2.4 \mathrm{~kg} / \mathrm{m}^{3}, 4.8 \mathrm{~kg} / \mathrm{m}^{3}$ および $7.2 \mathrm{~kg} / \mathrm{m}^{3}$ の結果を示している。なお, JCI-AAR-3：1987 「コンクリートのアルカリ骨材反応性判定試験方法 (案)」 では, 水酸化ナトリウムの添加量は酸化ナトリウム当量 で $2.4 \mathrm{~kg} / \mathrm{m}^{3}$ である。この結果をもとに，コンクリート によってアルカリ骨材反応による長さ変化を調べる実験 では, 水酸化ナトリウムの添加量を酸化ナトリウム当量 で $7.2 \mathrm{~kg} / \mathrm{m}^{3}$ とした.

\section{$2 \cdot 3$ 測定方法}

$2 \cdot 3 \cdot 1$ 長さ変化試験 モルタルの長さ変化試験に は， $40 \times 40 \times 160 \mathrm{~mm}$ の角柱供試体を用いた。 モルタル は, 打設後 24 時間型枠内に置き, 脱型直後に初期值の 測定を行った。供試体は, 温度 $40 \pm 2^{\circ} \mathrm{C}$, 湿度 $95 \%$ 以 上に保たれた密閉容器内で貯蔵した。測定は，1 月月毎 とし，測定 24 時間前に $20 \pm 2{ }^{\circ} \mathrm{C}$ の恒温室に移動し，長 さ変化の測定を行った.

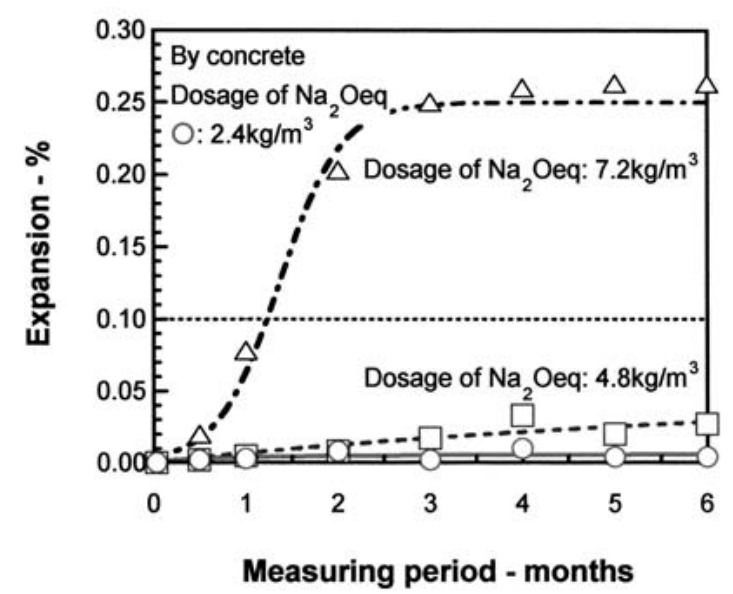

Fig. 4 Effect of $\mathrm{Na}_{2} \mathrm{Oeq}$ on expansion of concrete.

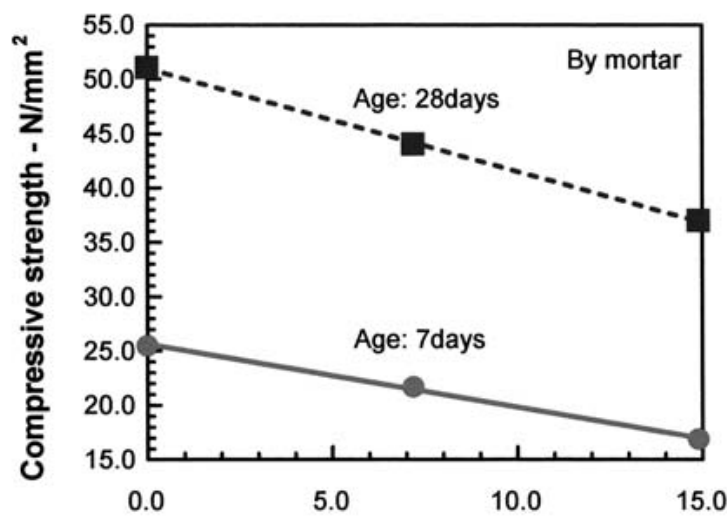

Fly ash to binder ratio in weight - \%

Fig. 6 Effect of fly ash on compressive strength.

コンクリートの長さ変化試験には, $100 \times 100 \times 400 \mathrm{~mm}$ の角柱供試体を用いた。コンクリートは，打設後 24 時 間型枠内に置き，脱型直後に初期值の測定を行った。供 試体は, 十分に水を含んだ布で覆った後, ポリエチレン ラップで包み, さらにビニール袋の中で密閉し, 温度 $40 \pm$ $2^{\circ} \mathrm{C}$ に保たれた定温器内に貯蔵した。測定は，1 ケ月毎と し, 測定 24 時間前に $20 \pm 2^{\circ} \mathrm{C}$ の恒温室に移動し，長さ 変化の測定を行った.

$2 \cdot 3 \cdot 2$ コンクリート中の水酸化アルミニウムおよ び水酸化カルシウムの定量 コンクリート中の水酸化ア ルミニウムおよび水酸化カルシウムの定量には, 自動示 差熱・熱重量同時測定装置を用いた。 $250 〜 320^{\circ} \mathrm{C}$ およ び $400 \sim 500^{\circ} \mathrm{C}$ での水酸化アルミニウムおよび水酸化力 ルシウムの脱水反応に伴う質量減少量から, コンクリー トに含まれる水酸化アルミニウム量および水酸化カルシ ウム量を算出した。

\section{3 実験結果および考察}

$3 \cdot 1$ 代表的なアルカリ骨材反応抑制材料の効果 Fig. 5 は, Table 1 に示されるモルタルのうち, フライアッ シュを用いたモルタルの膨張量を示したものである。困 中の○，ロ拈よびム，それぞれ，フライアッシュを質 量比でセメントと $0.0 \%, 7.2 \%$ および $14.9 \%$ 置換した結果 を示している。フライアッシュは，使用量にほぼ比例し 


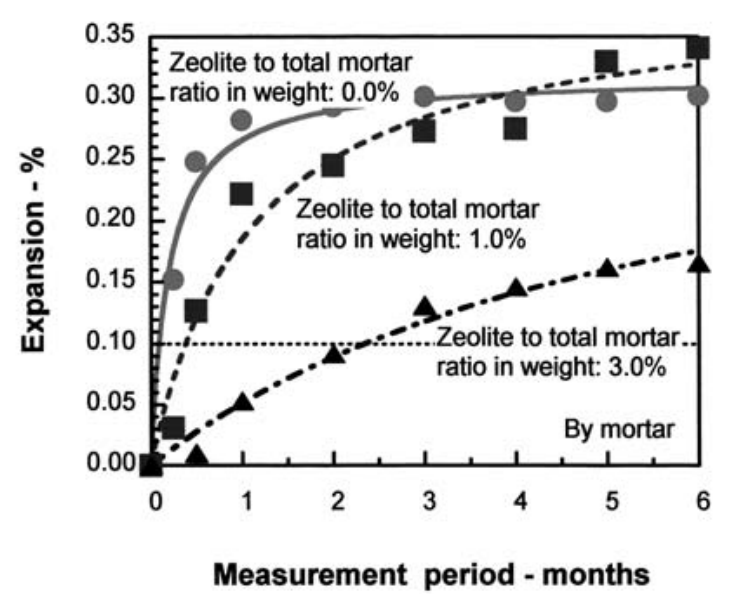

Fig. 7 Effect of zeolite on expansion of mortar.

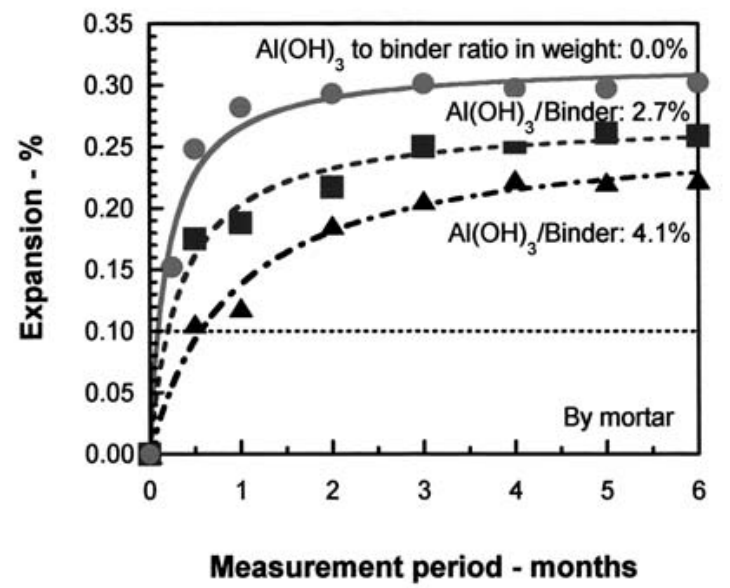

Fig. 9 Effect of $\mathrm{Al}(\mathrm{OH})_{3}$ on expansion of mortar.

て，アルカリ骨材反応による膨張が小さくなっているこ とが分かる。一方，Fig. 6 は，フライアッシュを用いた モルタルの材齢 7 日扎よび 28 日に打ける圧縮強度を示 したものである. 罒中の○抽びは，それぞれ，材齢 が 7 日および 28 日の結果を示している。 ただし, これら の結果を得るために用いたモルタルには，水酸化ナトリ ウムは使用していない。これらの図に示されるように， フライアッシュを用いた場合には，アルカリ骨材反応に よる膨張が小さくなると同時に, 圧縮強度も低下してい ることが分かる。

Fig. 7 は，核がナトリウムである合成 A 型ゼオライト を用いたモルタルの膨張量を示したものである。モルタ ルの配合は, Table 1 の混和材を用いていないものであ る。罒中の○，およびムは，それぞれ，合成 A 型ゼオ ライトをモルタルの全質量に対して外割りで $0.0 \%, 1.0 \%$ および $3.0 \%$ 添加した結果である.アルカリ骨材反応に対 して抑制効果をもつとされるゼオライトは, 核が水素イ オンの天然ゼオライトである。核である水素イオンとコ ンクリート中のナトリウムイオン等との間でイオン交換 が生じることで，アルカリ骨材反応が抑制されると一般 にいわれている，核がナトリウムの合成 A 型ゼオライト を用いた場合， $1.0 \%$ 程度では添加していないものと同程 度あるいはより膨張する。しかし， $3.0 \%$ と多量に添加す

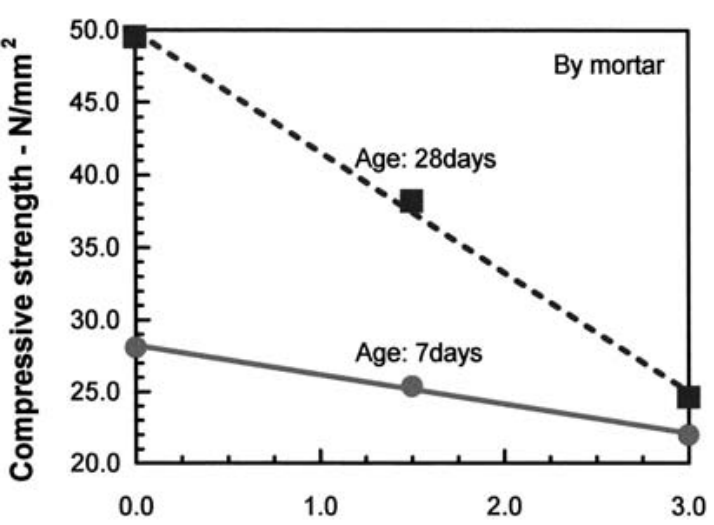

Zeolite to total mortar ratio in weight - \%

Fig. 8 Effect of zeolite on compressive strength.

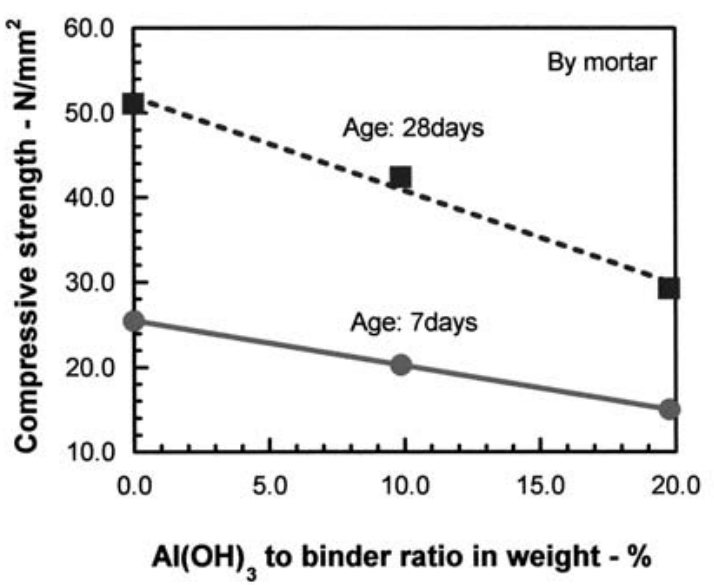

Fig. 10 Effect of $\mathrm{Al}(\mathrm{OH})_{3}$ on compressive strength.

ると，ゼオライトがナトリウムイオン等を吸着する効果 によって，アルカリ骨材反応による膨張が小さくなって いる。また，Fig. 8 は，合成 A 型ゼオライトを用いたモ ルタルの材齢 7 日および 28 日における圧縮強度を示し たものである。罒中の○扎よびロは，それぞれ，材齢が 7 日扎よび 28 日の結果である。な打，これらの結果を得 るために用いたモルタルには, 水酸化ナトリウムは使用 していない．合成 A 型ゼオライトを添加した場合には， 圧縮強度が大きく低下していることが分かる，実用性の 面からは課題が多いが，ゼオライトもアルカリ骨材反応 を抑制する可能性のある材料の一つである.

\section{$3 \cdot 2$ 水酸化アルミニウムの効果}

Fig. 9 は, Table 1 に示されるモルタルのうち, 水酸化 アルミニウムを用いたものの膨張量を示したものである. 図中の○，および二は，それぞれ，水酸化アルミニウ ムを質量比でセメントと $0.0 \%, 2.7 \%$ および $4.1 \%$ 置換し た結果を示している. 水酸化アルミニウムを $4.1 \%$ 添加し たものは，フライアッシュを $7.2 \%$ 添加したものとほぼ同 程度の膨張量になっている。 また Fig. 10 は, 水酸化ア ルミニウムを用いたモルタルの材齢 7 日抢よび 28 日にお ける圧縮強度を示したものである。困中の○およびロは， それぞれ，材齢が 7 日打よび 28 日の結果である。これら の結果を得るために用いたモルタルには, 水酸化ナトリ 


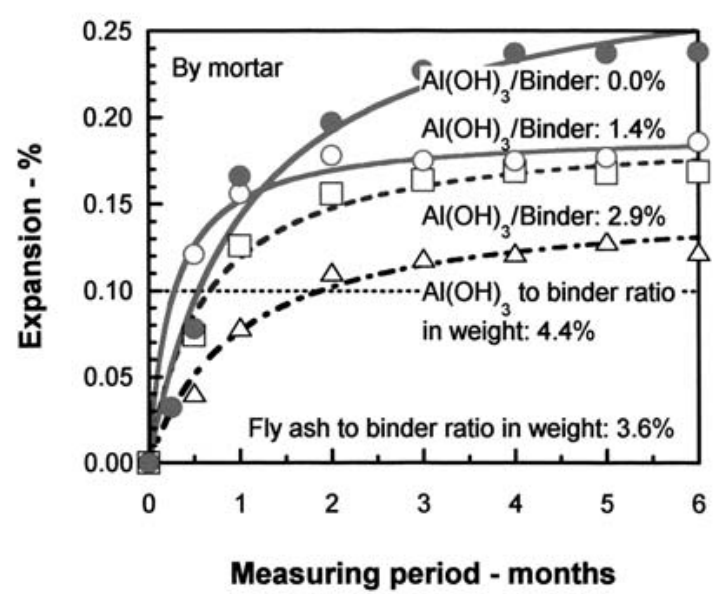

Fig. 11 Effect of $\mathrm{Al}(\mathrm{OH})_{3}$ on expansion of mortar with $3.6 \%$ of fly ash.

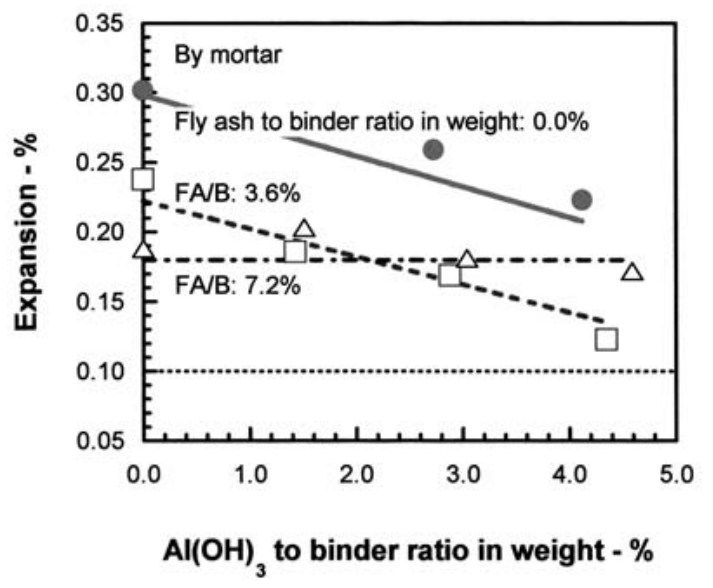

Fig. 13 Effect of $\mathrm{Al}(\mathrm{OH})_{3}$ on expansion of mortar.

ウムは使用していない．水酸化アルミニウムを用いた場 合にも，アルカリ骨材反応による膨張が小さくなると同 時に，圧縮強度も低下していることが分かる．フライアッ シュを $7.2 \%$ 用いた場合と水酸化アルミニウムを $4.1 \%$ 用 いた場合の膨張量は，ほぼ同程度であるが，このときの 圧縮強度も, Fig. 6 扎よび Fig. 10 より, 材歯 28 日にお いて $45 \mathrm{~N} / \mathrm{mm}^{2}$ 程度でほぼ同じであった。

Fig. 11 およびFig. 12 は，それぞれ，フライアッシュ を質量比で結合材の $3.6 \%$ および $7.2 \%$ 用いたモルタルに 打いて，水酸化アルミニウムがアルカリ骨材反応による 膨張に及ぼす影響を調べたものである．Fig. 11 中の○

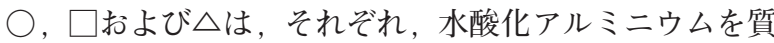
量比で結合材の $0.0 \% ， 1.4 \% ， 2.9 \%$ および $4.4 \%$ 添加した 結果を示している。また，Fig. 12 中の○，○，口扰よ びメは，それぞれ，水酸化アルミニウムを質量比で結合 材の $0.0 \% ， 1.5 \% ， 3.0 \%$ 打よび 4.6\% 添加した結果を示し ている. Fig. 11 に示されるように，フライアッシュを結 合材の $3.6 \%$ 用いた場合には，水酸化アルミニウムの効果 が顕著であるのに対し，Fig. 12 に示されるように，フラ イアッシュを結合材の $7.2 \%$ 用いた場合には，水酸化アル ミニウムの効果が小さいことが分かる.

Fig. 13 に測定期間 6 ヶ月に扎けるモルタルのアルカリ 骨材反応による膨張量と水酸化アルミニウムの添加量の

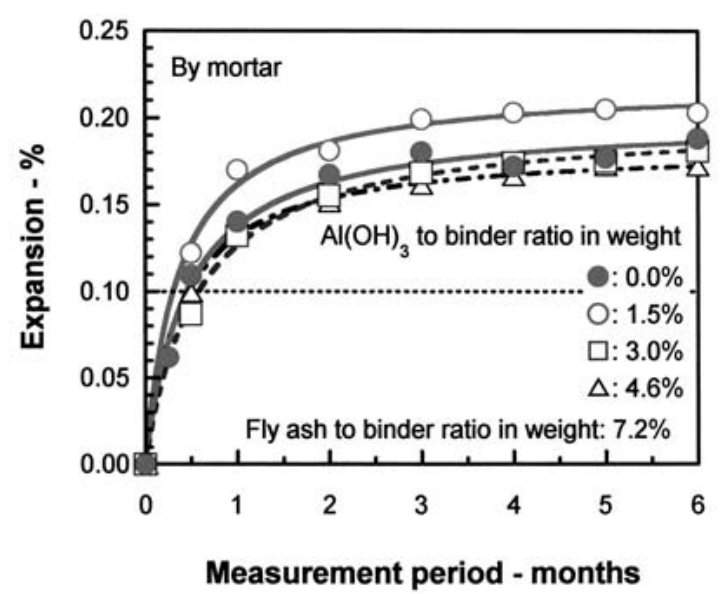

Fig. 12 Effect of $\mathrm{Al}(\mathrm{OH})_{3}$ on expansion of mortar with $7.2 \%$ of fly ash.

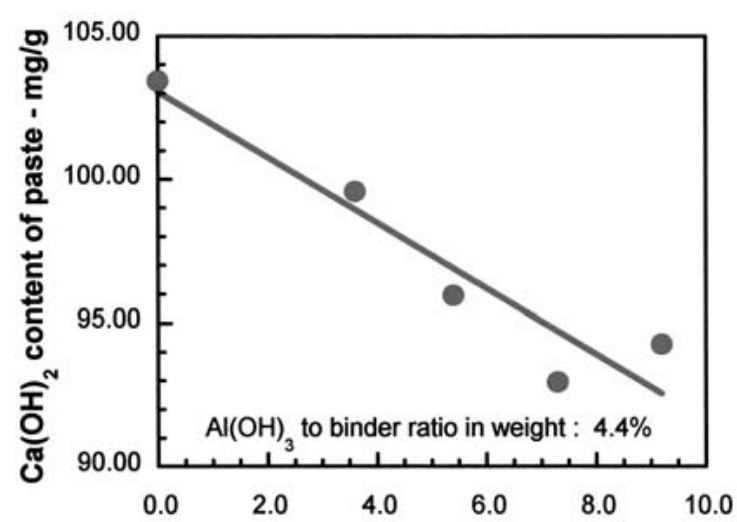

Fly ash to binder ratio in weight - \%

Fig. 14 Relationship between $\mathrm{Ca}(\mathrm{OH})_{2}$ content and fly ash to binder ratio.

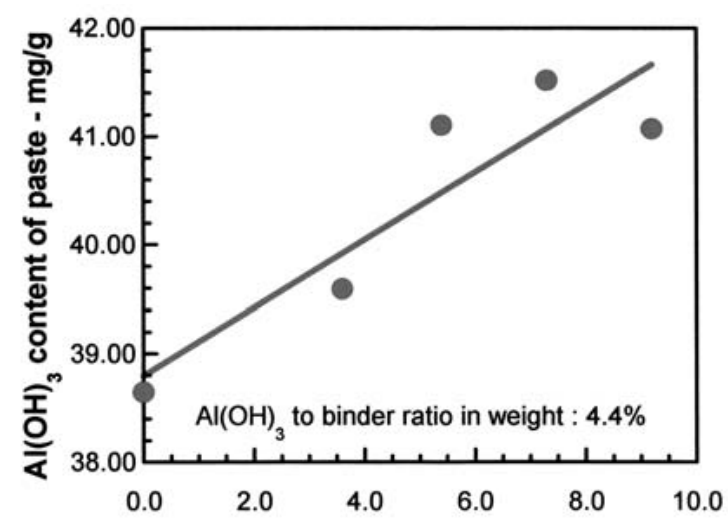

Fly ash to binder ratio in weight - \%

Fig. 15 Relationship between $\mathrm{Al}(\mathrm{OH})_{3}$ content and fly ash to binder ratio.

関係を示す。この四より，フライアッシュの添加量が $0.0 \%$ の場合打よび $3.6 \%$ の場合には，水酸化アルミニウ ムの添加によって膨張を小さくする効果はほぼ同程度で あるのに対し，フライアッシュを $7.2 \%$ 用いた場合には， 水酸化アルミニウムの添加量が増加しても，膨張量の変 化が小さいことが分かる。また，質量比で $3.6 \%$ のフライ 


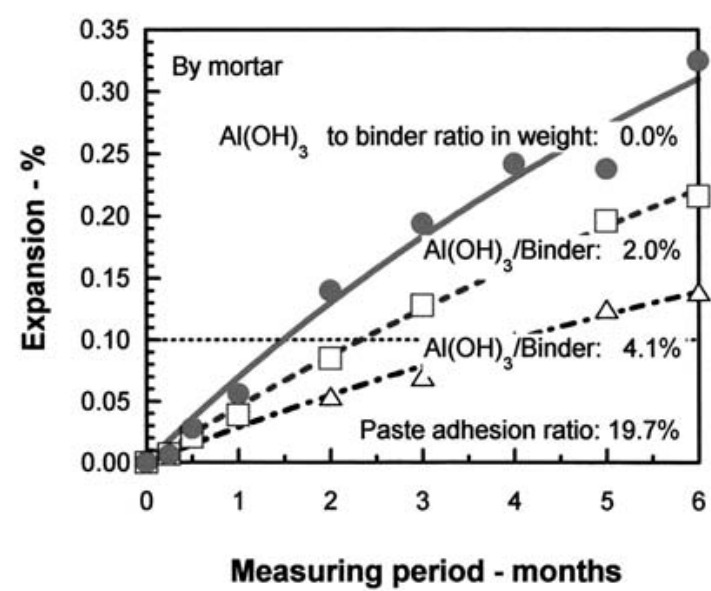

Fig. 16 Effect of $\mathrm{Al}(\mathrm{OH})_{3}$ on recycled aggregate.

アッシュと $4.4 \%$ の水酸化アルミニウムを併用したものは, フライアッシュのみを $7.2 \%$ 用いたものよりも , アルカリ 骨材反応による膨張が小さくなっている.

Fig. 14 打よび Fig. 15 は，水酸化アルミニウムを質量 比で結合材の $4.4 \%$ 添加し，水結合材比を $30 \%$ としたぺー ストに含まれる水酸化カルシウム量および水酸化アルミ ニウム量の測定結果を示したものである。ただし，この 実験に用いた結合材は, 普通ポルトランドセメント，フ ライアッシュおよび水酸化アルミニウムで, 測定時の材 齢は 28 日である。また，ペースト中に含まれる全アルカ リ量が，酸化ナトリウム当量でセメントの $2.0 \%$ になるよ うに水酸化ナトリウムを添加している. Fig. 14 より, フ ライアッシュ量の増加に伴い, 水酸化カルシウム量が減少 していることが分かる. また, Fig. 15 より, フライアッ シュ量の増加に伴い, 水酸化アルミニウムの残存する量 が多くなっていることが分かる。すなわち，フライアッ シュの使用量が増加することにより, 消費される水酸化 カルシウム量が増え, ペーストの $\mathrm{pH}$ が下がることで, 水 酸化アルミニウムの溶解量が減少したものと考えられる.

\section{$3 \cdot 3$ 種々の骨材に水酸化アルミニウムが及ぼす効果}

Fig. 16 は，海洋構造物として 30 年間供用されたコン クリート構造物のコンクリート塊より作成した再生細骨 材を用いて, 水酸化アルミニウムがアルカリ骨材反応に よる膨張に及ぼす影響を調べた結果である。コンクリー 卜構造物は, アルカリ骨材反応による劣化によって, 数 回にわたる補修が行われたもので，その構造物に用いら れた粗骨材は, Type Tと同じものである。なお，罒中

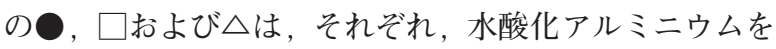
質量比で結合材の $0.0 \%, 2.0 \%$ および $4.1 \%$ 用いた結果を 示している。 バージン骨材と同様に, 水酸化アルミニウ ムを結合材の $4.1 \%$ 添加すれば，アルカリ骨材反応に対し て十分な効果が得られている。

Fig. 17 は, Type $\mathrm{H}$ および Type $\mathrm{K}$ の骨材を用いて, 水酸化アルミニウムがアルカリ骨材反応による膨張に及 ぼす影響を調べたものである。罒の左から順番に，混和 材を用いていないもの, 水酸化アルミニウムを質量比で 結合材の 10.0\% 用いたもの，フライアッシュを $15.0 \%$ 用 いたもの，フライアッシュおよび水酸化アルミニウムを， それぞれ，3.5\% 扎よび $4.5 \%$ 併用した結果である. フライ

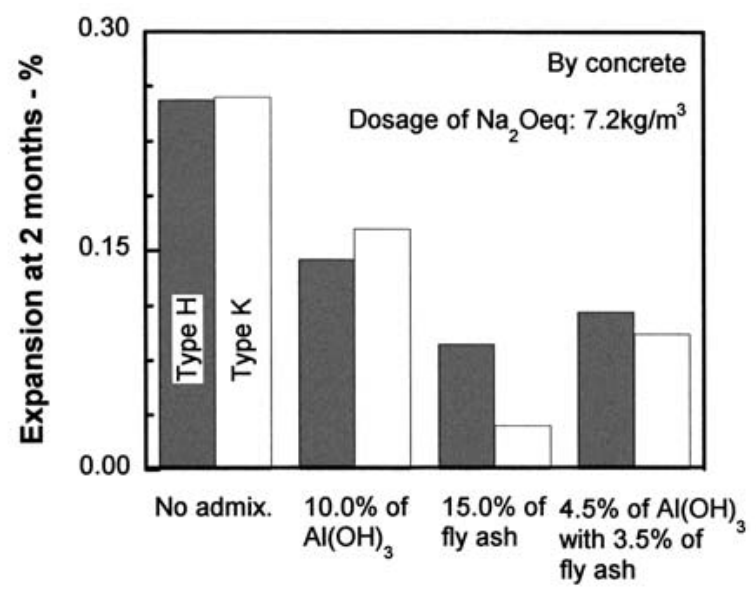

Fig. 17 Effect of $\mathrm{Al}(\mathrm{OH})_{3}$ on different aggregate.

アッシュおよび水酸化アルミニウムを併用したものは, フライアッシュのみを $15.0 \%$ 用いた場合および水酸化ア ルミニウムのみを $10.0 \%$ 用いた場合と同程度まで膨張が 小さくなっていることが分かる。

\section{4 ま と め}

水酸化アルミニウムは，アルカリ骨材反応による膨張 を抑制可能な材料であり，その効果は，フライアッシュ と併用することで，より高めることが可能であることを 示した。しかし，フライアッシュを多量に用いた場合は， 水酸化アルミニウムがコンクリート中に溶解せずに残存 するため，その効果を期待できない場合がある。水酸化 アルミニウムによるアルカリ骨材反応抑制効果は, 再生 骨材や産地の異なる骨材に対しても有効であり, フライ アッシュおよび水酸化アルミニウムを質量比で結合材の $3.5 \%$ および $4.5 \%$ 併用することで，フライアッシュを質量 比で結合材の $15.0 \%$ 用いる場合と同程度の効果が得られ る可能性がある。

\section{参 考 文 献}

1) Japan Society of Civil Engineers, "State-of-the-Art Report on the Countermeasures for the Damage Due to Alkali-Silica Reaction”, pp.I-26-28 (2005).

2 ) S. Diamond, "Effect of Two Danish Fly Ashes on Alkali Contents of Pore Solutions of Cement-Fly Ash Pastes", Cement and Concrete Research, Vol.11, No.3, pp.383-394 (1981).

3) M. Kawamura, K. Takemoto and S. Hasaba, "Effect of silica fume on alkali-silica expansion in mortars", Cement and Concrete, No.469, pp.29-35 (1986).

4 ) The Society of Materials Science, Japan, "Concrete konwazairyo handbook ”, p.291 (2004) NTS.

5 ) T. Fujiwara, E. Satou and J. Dong, "Adaptability of zeolite as an admixture for preventing alkali-aggregate reaction”, Japan Cement Association proceedings of Cement and Concrete, No.49, pp.674-679 (1995).

6 ) T. Takahashi, N. Nagano, M. Yahata and Y. Hama, "Inhibition of alkali-aggregate reaction in concrete by using zeolite”, Proceedings of the Japan Concrete Institute, Vol.16, No.1, pp.1099-1104 (1994). 